\title{
Prenatal screening of sialic acid storage disease and confirmation in cultured fibroblasts by LC-MS/MS
}

\author{
Jeroen van den Bosch • Linda F. Oemardien • Malgorzata I. Srebniak • \\ Monique Piraud • Jan G. M. Huijmans • Frans W. Verheijen • George J. G. Ruijter
}

Received: 10 March 2011 /Revised: 10 May 2011 /Accepted: 11 May 2011 /Published online: 27 May 2011

(C) The Author(s) 2011. This article is published with open access at Springerlink.com

\begin{abstract}
Sialic acid storage disease (SASD) is an inborn error resulting from defects in the lysosomal membrane protein sialin. The SASD phenotypical spectrum ranges from a severe presentation, infantile sialic acid storage disease (ISSD) which may present as hydrops fetalis, to a relatively mild form, Salla disease. Screening for SASD is performed by determination of free sialic acid (FSA) in urine or amniotic fluid supernatant (AFS). Subsequent diagnosis of SASD is performed by quantification of FSA in cultured fibroblasts and by mutation analysis of the sialin gene, SLC17A5. We describe simple quantitative procedures to determine FSA as well as conjugated sialic acid in AFS, and FSA in cultured fibroblasts, using isotope dilution $\left({ }^{13} \mathrm{C}_{3}\right.$-sialic acid) and multiple reaction monitoring LC-ESI-MS/MS. The whole procedure can be performed in 2-4 h. Reference values in AFS were $0-8.2 \mu \mathrm{mol} / \mathrm{L}$ for 15-25 weeks of gestation and 3.2-12.0 $\mu \mathrm{mol} / \mathrm{L}$ for $26-$ 38 weeks of gestation. In AFS samples from five fetuses affected with ISSD FSA was 23.9-58.9 $\mu \mathrm{mol} / \mathrm{L}$ demonstrating that this method is able to discriminate ISSD pregnancies from normal ones. The method was also
\end{abstract}

Communicated by: Cornelis Jakobs

Competing interest: None declared

J. van den Bosch • L. F. Oemardien • M. I. Srebniak •

J. G. M. Huijmans · F. W. Verheijen · G. J. G. Ruijter $(\bowtie)$

Department Clinical Genetics, Erasmus Medical Center,

Dr. Molewaterplein 50,

3015GE Rotterdam, The Netherlands

e-mail: g.ruijter@erasmusmc.nl

\section{Piraud}

Laboratoire des Maladies Héréditaires du Métabolisme et Dépistage Néonatal, Centre de Biologie Est, Hospices Civils de Lyon,

Bron, France validated for determination of FSA in fibroblast homogenates. FSA in SASD fibroblasts (ISSD; $20-154 \mathrm{nmol} / \mathrm{mg}$ protein, intermediate SASD; $12.9-15.1 \mathrm{nmol} / \mathrm{mg}$, Salla disease; 5.9-7.4 nmol $/ \mathrm{mg}$ ) was clearly elevated compared to normal controls $(0.3-2.2 \mathrm{nmol} / \mathrm{mg})$. In conclusion, we report simple quantitative procedures to determine FSA in AFS and cultured fibroblasts improving both prenatal diagnostic efficacy for ISSD as well as confirmatory testing in cultured fibroblasts following initial screening in urine or AFS.

$\begin{array}{ll}\text { Abbreviations } \\ \text { AFS } & \text { Amniotic fluid supernatant } \\ \text { CSA } & \text { Conjugated sialic acid } \\ \text { CVS } & \text { Chorion villus sample } \\ \text { FSA } & \text { Free sialic acid } \\ \text { IS } & \text { Internal standard } \\ \text { ISSD } & \text { Infantile sialic acid storage disease } \\ \text { QC } & \text { Quality control } \\ \text { SA } & \text { Sialic acid } \\ \text { SASD } & \text { sialic acid storage disease } \\ \text { TSA } & \text { Total sialic acid }\end{array}$

\section{Introduction}

Sialic acid storage disease (SASD) is an autosomal recessive disorder resulting from a defect in sialin, a protein involved in transport of sialic acid ( $\mathrm{N}$-acetylneuraminic acid) across the lysosomal membrane (Suwannarat 2005, Verheijen et al. 1999). SASD exhibits a broad phenotypical spectrum (Aula et al. 2000). The main features of a severe presentation, infantile sialic acid storage disease (ISSD; 
OMIM 269920), include coarse facies, hepatomegaly, failure to thrive, developmental delay and early death. ISSD may present as hydrops fetalis (Froissart et al. 2005, Lefebvre et al. 1999). A mild presentation, Salla disease (OMIM 604369), exists mainly in the Finnish population and is characterised by hypotonia, developmental delay and ataxia (Varho et al. 2002).

Sialin deficiency results in accumulation of free sialic acid (FSA) in lysosomes of many cell types. Tissue accumulation of FSA is reflected by increased excretion in urine allowing for postnatal screening of SASD by determination of FSA. Once elevated urinary excretion is established, confirmation of SASD is possible by quantification of FSA in cultured fibroblasts or by mutation analysis of the sialin gene, SLC17A5 (Verheijen et al. 1999).

Prenatal diagnosis of SASD in families with a known index case is preferentially performed by mutation analysis (Aula and Aula 2006). However, to investigate ISSD (along other possible causes) in prenatal studies of hydrops fetalis, measurement of FSA in amniotic fluid supernatant (AFS) is more appropriate as a first screening test.

Traditional methods for determination of sialic acid in urine and AFS include spectrophotometric or fluorimetric thiobarbituric acid assays ('Warren test'), thin-layer chromatography (TLC), enzymatic tests and HPLC using UV or fluorimetric detection (Gopaul and Crook 2006). In the Warren test interfering substances, such as sugars, may contribute to absorbance, resulting in false positive measurements, while in TLC a moderate elevation of FSA may be overlooked. In CVS or cultured fibroblasts/amniocytes HPLC with pulsed amperometric detection has been used (Renlund and Aula 1987, Renlund et al. 1986). The thiobarbituric assay can be used for cell homogenates, but requires extensive sample clean-up by ion exchange chromatography (Mancini et al. 1992).

Recently, LC-MS/MS methods have been reported to quantify FSA in urine (Van der Ham et al. 2007) and cerebrospinal fluid (Van der Ham et al. 2010). In this report we describe simple quantitative procedures using LC-MS/MS to assay FSA in AFS as well as in cultured fibroblasts.

\section{Materials and methods}

\section{Reagents}

Formic acid (98\%), acetonitrile, water (HPLC grade), ammonium formate $(>99 \%$ p.a), and sialic acid (Nacetylneuraminic acid $\geq 98 \%$ ) were purchased from Fluka (St. Louis, MO, USA). Sulfuric acid (95-97\%) and Sialyllactose from human milk $(\geq 97 \%$ ) was obtained from Sigma-Aldrich (St. Louis, MO). $1,2,3-{ }^{13} \mathrm{C}_{3}-\mathrm{N}-$ acetylneuraminic acid (internal standard, IS) was obtained from Omicron Biochemicals (South Bend, IN, USA).

\section{Sample preparation}

Amniotic fluid samples $(n=151)$ were obtained from control pregnancies after routine prenatal testing was completed in the laboratory of prenatal cytogenetics in our university hospital. These control pregnancies (not affected with SASD) were used to determine reference values for FSA and CSA in the second and third trimester of pregnancy. Amniotic fluid supernatant (AFS) was prepared by centrifugation for $10 \mathrm{~min}$ at $15000 \mathrm{x}$ g. AFS samples were stored at $-80^{\circ} \mathrm{C}$ for $0-2$ years. Five AFS samples from fetuses affected with ISSD were obtained from the Laboratoire des Maladies Héréditaires du Métabolisme et Dépistage Néonatal, Centre de Biologie Est, Hospices Civils de Lyon, France. These samples were stored at $-20^{\circ} \mathrm{C}$ for $0-7$ years prior to FSA determination. Another 11 AFS samples from control pregnancies (not affected with SASD), stored at $-20^{\circ} \mathrm{C}$ for $6-8$ years, were used to assess whether storage temperature had an effect on FSA concentration in AFS. In addition, six AFS samples from hydrops fetalis pregnancies not caused by ISSD were analysed.

For analysis of FSA, $25 \mu \mathrm{L}$ of IS $(0.85 \mathrm{mmol} / \mathrm{L})$ was added to $125 \mu \mathrm{L}$ AFS. For analysis of total sialic acid (TSA) $25 \mu \mathrm{IS}$ $(0.85 \mathrm{mmol} / \mathrm{L})$ was added to $25 \mu \mathrm{l}$ of AFS, followed by addition of $100 \mu \mathrm{L}$ sulphuric acid $(63 \mathrm{mmol} / \mathrm{L})$ and incubation for $1 \mathrm{~h}$ at $80^{\circ} \mathrm{C}$ to release all conjugated sialic acid (CSA). Samples were analysed after cooling down. CSA was calculated by subtraction of FSA from TSA and expressed as $\mathrm{nmol} / \mathrm{mg}$ protein. Protein concentration in AFS was determined using the Pierce BCA Protein Assay kit (Thermo Scientific) according to the instructions of the manufacturer.

Skin fibroblast cultures of 10 patients carrying a deficiency of sialin (six affected with ISSD, two with intermediate form of SASD and two with Salla disease) as well as cultures from 24 controls (not affected with SASD) were provided by the European Cell Bank, Rotterdam, The Netherlands. Fibroblasts were cultured under standard conditions in Ham's F10 medium supplemented with $10 \%$ fetal calf serum, harvested by trypsinisation and stored as cell pellets at $-80^{\circ} \mathrm{C}$. A cell pellet was prepared from one $75 \mathrm{~cm}^{2}$ flask. Homogenates were prepared by resuspending one cell pellet in $200 \mu \mathrm{L}$ of IS $(85 \mu \mathrm{mol} / \mathrm{L})$ followed by sonication for $10 \mathrm{sec}$ at $130 \mathrm{~W}$. Ten $\mu \mathrm{L}$ of homogenate was taken out to determine protein as described above. For analysis of FSA, $300 \mu \mathrm{L}$ of acetonitril was added to the remaining cell homogenate. Following mixing the solution was centrifuged $(10 \mathrm{~min}$ at $15000 \times \mathrm{g})$ and the supernatant was transferred to a glass vial and dried under a flow of nitrogen. The residue was dissolved in $200 \mu \mathrm{L}$ HPLC water and analysed. 


\section{Calibration curve}

An eight-point calibration curve with concentrations of 0,5 , $10,50,100,200,425$ and $850 \mu \mathrm{mol} / \mathrm{L} \mathrm{SA}$ in HPLC water was prepared. To $125 \mu \mathrm{L}$ of each of the standards $25 \mu \mathrm{L}$ of IS $(0.85 \mathrm{mmol} / \mathrm{L})$ was added.

\section{LC-MS/MS}

The LC-MS/MS system consisted of a TSQ Quantum triple quadrupole mass spectrometer, interfaced with an electron spray ionisation source (Thermo Scientific, USA) connected to a Surveyor autosampler and Surveyor MS Pump Plus (Thermo Sientific). Using the autosampler $10 \mathrm{uL}$ aliquots of samples or standards were injected onto a Waters dC18 guard column $(3.5 \mu \mathrm{m}, 2.1 \times 20 \mathrm{~mm})$ connected to a Waters Atlantis dC18 analytical column $(3.5 \mu \mathrm{m}, 2.1 \times 100 \mathrm{~mm})$ (Waters, Massachusetts, USA). The analytical column temperature was kept at $35^{\circ} \mathrm{C}$ and flow rate was $0.3 \mathrm{~mL} / \mathrm{min}$. The following elution profile was used: $0-4 \mathrm{~min}$, linear gradient from $100 \%$ solvent A (0.05 M ammoniumformate, $\mathrm{pH} 3.0)$ to $100 \%$ solvent $\mathrm{B}$ (100\% acetonitrile); $4-6$ min $100 \%$ solvent $\mathrm{B}$; $6-12 \mathrm{~min}$ $100 \%$ solvent A. Between 0-2.5 min and 6.13-12 min the solvent was sent to waste using a divert valve to avoid unnecessary introduction of solvents in the source. The retention time of SA and IS was $5 \mathrm{~min}$.

The MS/MS was operated in the negative mode with a capillary voltage of $5.0 \mathrm{kV}$. The tube lens settings for SA and IS were 88 and $93 \mathrm{~V}$ respectively. As a drying gas nitrogen (sheath gas and auxiliary) was used at a flow rate of 50 and $30 \mathrm{~L} / \mathrm{min}$ respectively, with a source temperature of $325^{\circ} \mathrm{C}$. The collision cell was operated at $28 \mathrm{eV}$ at a gas pressure of $1.4 \mathrm{mTorr}$ Argon. Mass resolution of Q1 and Q3 quadrupoles was $0.7 \mathrm{Da}$. Detection was performed by selecting negatively single charged SA ions $\mathrm{m} / z$ 308.0 $>86.9$ and IS $\mathrm{m} / z$ 311.0>89.9. Xcalibur software (Version 1.4, SP3, Thermo Finnigan, USA) was used for instrument control, data acquisition and data processing.

\section{Method validation}

Linearity was determined with nine different concentrations of FSA up to $1700 \mu \mathrm{mol} / \mathrm{L}$ and eight different concentrations of sialyllactose up to $1000 \mu \mathrm{mol} / \mathrm{L}$. Hydrolysis of sialyllactose was performed as described for CSA in AFS (see above). Limit of detection (LOD, signal-to-noise ratio 3:1) and limit of quantitation (LOQ, signal-to-noise ratio 10:1) were determined using a $5 \mu \mathrm{mol} / \mathrm{L}$ SA standard, four AFS samples containing 1.2-12 $\mu \mathrm{mol} / \mathrm{L}$ FSA and four fibroblast homogenates containing 0.7-4.9 $\mu \mathrm{mol} / \mathrm{L}$ FSA. Recovery was evaluated by addition of 49 or $106 \mathrm{nmol} \mathrm{FSA}$ and $57 \mathrm{nmol}$ sialyllactose to $500 \mu \mathrm{L}$ AFS and $1.5 \mathrm{nmol} \mathrm{FSA}$ to
$300 \mu \mathrm{L}$ fibroblast homogenate. Precision (intra-assay and inter-assay variation) was assessed with two QC AFS samples containing 4.3 (normal) and 38.1 (high) $\mu \mathrm{mol} / \mathrm{L} \mathrm{FSA}$ and 194 and $274 \mu \mathrm{mol} / \mathrm{L}$ CSA respectively.

\section{Results}

Amniotic fluid supernatant

Calibration curves were linear $\left(\mathrm{R}^{2}\right.$ 0.999) up to at least $1700 \mu \mathrm{mol} / \mathrm{L}$ for $\mathrm{FSA}$ and $1000 \mu \mathrm{mol} / \mathrm{L}$ for TSA (sialyllactose). Limit of detection (LOD) was $0.13 \mu \mathrm{mol} / \mathrm{L}$ for FSA and $0.6 \mu \mathrm{mol} / \mathrm{L}$ for TSA. Limit of quantitation (LOQ) was $0.36 \mu \mathrm{mol} / \mathrm{L}$ for FSA and $1.9 \mu \mathrm{mol} / \mathrm{L}$ for TSA. Intra-assay variation coefficients in AFS were $8.5 \%$ for FSA and $8.9 \%$ for CSA. Inter-assay variation of FSA in two QC samples was $19.4 \%$ (FSA $4.3 \mu \mathrm{mol} / \mathrm{L}$ ) and $12.4 \%$ (FSA $38.1 \mu \mathrm{mol} / \mathrm{L}$ ). For CSA, inter-assay variation in these two QC samples was $14.2 \%$ (CSA $194 \mu \mathrm{mol} / \mathrm{L}$ ) and $14.4 \%$ (CSA $274 \mu \mathrm{mol} / \mathrm{L}$ ). Recovery was $85-94 \%$ for FSA and $82-86 \%$ for CSA (sialyllactose).

Reference values for FSA in AFS were $2.8 \pm 1.8 \mu \mathrm{mol} / \mathrm{L}$ (average $\pm \mathrm{SD}$; range $0-8.2, \mathrm{n}=108$ ) for gestational age 15-25 weeks and $6.8 \pm 2.3 \mu \mathrm{mol} / \mathrm{L}$ (range 3.2-12.0, $\mathrm{n}=43$ ) for gestational age 26-38 weeks. While the AFS samples used to determine reference values were stored at $-80^{\circ} \mathrm{C}$, we tested whether storage at $-20^{\circ} \mathrm{C}$ resulted in different FSA concentration, e.g. higher values due to release of CSA. FSA values in 11 AFS samples stored for 6 to 8 years at $-20^{\circ} \mathrm{C}$ were all within the reference range determined with samples stored at $-80^{\circ} \mathrm{C}$. FSA concentration in AFS from five fetuses affected with ISSD ranged from 23.9 to $58.9 \mu \mathrm{mol} / \mathrm{L}$ and was clearly different from control values (Fig. 1). In six AFS samples from hydrops fetalis pregnancies with other cause, FSA values were within reference range $(2.4-4.9 \mu \mathrm{mol} / \mathrm{L}, \mathrm{n}=4$,

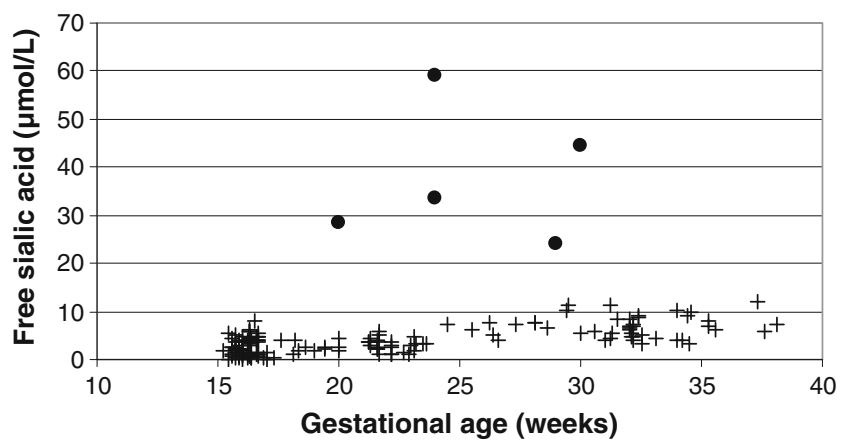

Fig. 1 Free sialic acid in amniotic fluid supernatant samples as a function of gestational age. Legend: + control samples $(n=151), \bullet$ ISSD samples 
gestational age 16-23 weeks; 7.0 and $11.2 \mu \mathrm{mol} / \mathrm{L}, \mathrm{n}=2$, gestational age 30 and 33 weeks).

CSA was expressed as nmol/mg protein, since a positive correlation existed between the concentrations of protein and CSA. Reference values for CSA were $41 \pm 16 \mathrm{nmol} / \mathrm{mg}$ protein (average $\pm \mathrm{SD}$; range $7-89, \mathrm{n}=103$ ) for gestational age $15-25$ weeks and $60 \pm 20 \mathrm{nmol} / \mathrm{mg}$ protein (average $\pm \mathrm{SD}$; range $26-102, n=24$ ) for gestational age $26-38$ weeks.

\section{Fibroblasts}

The limit of quantitation determined for FSA in fibroblast homogenates was $0.18 \mu \mathrm{mol} / \mathrm{L}$. Recovery of FSA was $104 \%$. Reference values for FSA in fibroblast homogenates were $1.0 \pm 0.7 \mathrm{nmol} / \mathrm{mg}$ protein (average \pm $\mathrm{SD}$; range $0.3-2.2, \mathrm{n}=24$ ). FSA measured in six fibroblast homogenates of patients known to be affected with ISSD was $20-154 \mathrm{nmol} / \mathrm{mg}$ protein with a median value of $31 \mathrm{nmol} / \mathrm{mg}$ protein. In two samples of patients with an intermediate form of SASD FSA was 12.9 and $15.1 \mathrm{nmol} / \mathrm{mg}$ protein, while in two samples of patients with Salla disease FSA was 5.9 and $7.4 \mathrm{nmol} / \mathrm{mg}$ protein.

\section{Discussion}

Sialic acid storage disease (SASD) may present with variable clinical severity. The most severe phenotype is hydrops fetalis (Froissart et al. 2005; Lefebvre et al. 1999). A number of other lysosomal storage disorders may also present as hydrops fetalis (Stone and Sidransky 1999) and diagnostic tests to investigate the cause of hydrops fetalis should include assays for these lysosomal disorders (Piraud et al. 1996; Kooper et al. 2006). To date HPLC has been the preferred method to measure FSA in AFS (Aula and Aula 2006). Other existing methods for determination of FSA in AFS such as the colorimetric Warren test or TLC have limited specificity or sensitivity or consist of elaborate procedures. The method described here combines high specificity and sensitivity with very simple sample preparation. FSA determination merely requires mixing of an AFS sample with a sialic acid stable isotope solution, immediately followed by LC-MS/MS. The whole procedure including sample preparation, analysis and calculation of results can be performed in $2-4 \mathrm{~h}$. The reference values described here $(0-6.3 \mu \mathrm{mol} / \mathrm{L} ; 95 \%$ confidence interval for gestational age 15-25 weeks) appear to be similar to previously published values determined by the thiobarbiturate assay $(1.7-5.3 \mu \mathrm{mol} / \mathrm{L}$; Aula and Aula 2006). FSA concentrations in AFS samples from five fetuses affected with ISSD (23.9 to $58.9 \mu \mathrm{mol} / \mathrm{L}$ ) were 2- to 9-fold the upper limit of the corresponding reference values and demonstrate that this method is able to distinguish ISSD pregnancies from normal controls. Interestingly, our results suggest that FSA is stable for at least 8 years of storage at $-20^{\circ} \mathrm{C}$ enabling retrospective diagnosis of ISSD. Our method may also be useful for prenatal diagnosis of ISSD in families with an ISSD index case with no additional molecular workup. Cases of Salla disease may only have mildly elevated FSA concentrations in AFS and in these instances the preferred method of prenatal diagnosis is mutation testing in a chorionic villus biopsy (Aula and Aula 2006).

In addition to measurement of FSA, we have performed analytical validation of CSA determination in AFS. Increased CSA in AFS has been reported in cases of sialidosis and galactosialidosis (Piraud et al. 1996; Kooper et al. 2006). Since sialidosis or galactosialidosis AFS samples were not available to us, we have not been able to establish the efficacy of our method in prenatal screening of these diseases.

Following demonstration of an elevated concentration of FSA in urine or AFS, confirmation of SASD is possible by quantification of FSA in cultured fibroblasts or amniocytes (Seppala et al. 1991; Renlund and Aula 1987). We show that our LC-MS/MS method is able to establish diagnosis of SASD in cultured fibroblasts. Reference values determined by LC-MS/MS $(1.0 \pm$ $0.7 \mathrm{nmol} / \mathrm{mg}$ protein) are fully compatible with previously reported values determined by the thiobarbiturate assay $(1.0 \pm 0.6 \mathrm{nmol} / \mathrm{mg}$ protein; Seppala et al. 1991) and fibroblasts of ISSD patients as well as Salla disease and SASD of intermediate severity contain elevated FSA levels compared to control fibroblasts. Moreover, the level of FSA correlated with the severity of disease. Sample preparation is simple and can be completed within an hour, which is much faster than HLPC or, in particular, the thiobarbituric assay which requires extensive sample clean-up by ion exchange chromatography. Our method may also be useful to screen for ISSD in CVS or amniocytes, but this needs to be validated.

In conclusion, this report describes simple quantitative procedures using LC-MS/MS to assay free and conjugated sialic acid in amniotic fluid supernatant as well as free sialic acid in cultured fibroblasts.

Open Access This article is distributed under the terms of the Creative Commons Attribution Noncommercial License which permits any noncommercial use, distribution, and reproduction in any medium, provided the original author(s) and source are credited.

\section{References}

Aula N, Aula P (2006) Prenatal diagnosis of free sialic acid storage disorders (SASD). Prenat Diagn 26:655-658 
Aula N, Salomäki P, Timonen R et al. (2000) The spectrum of SLC17A5-gene mutations resulting in free sialic acid-storage diseases indicates some genotype-phenotype correlation. Am J Hum Genet 67:832-840

Froissart R, Tourret S, Bonnet V et al. (2005) Clinical, morphological, and molecular aspects of sialic acid storage disease manifesting in utero. J Med Genet 42:829-836

Gopaul KP, Crook MA (2006) The inborn errors of sialic acid metabolism and their laboratory investigation. Clin Lab 52:155-169

Kooper AJA, Janssens PMW, de Groot ANJA et al. (2006) Lysosomal storage diseases in non-immune hydrops fetalis pregnancies. Clin Chim Acta 371:176-182

Lefebvre G, Wehbe G, Heron D, Vautjoer Brouzes D, Choukroun JB, Darbois Y (1999) Recurrent nonimmune hydrops fetalis: a rare presentation of sialic acid storage disease. Genet Couns $10: 277-284$

Mancini GM, Hu P, Verheijen FW et al. (1992) Salla disease variant in a Dutch patient. Potential value of polymorphonuclear leucocytes for heterozygote detection. Eur J Pediatr 151:590-595

Piraud M, Froissart R, Mandon G, Bernard A, Maire I (1996) Amniotic fluid for screening of lysosomal storage diseases presenting in utero (mainly as non-immune hydrops fetalis). Clin Chim Acta 248:143-155
Renlund M, Aula P (1987) Prenatal detection of Salla disease based upon increased free sialic acid in amniocytes. Am J Med Genet 28:377-384

Renlund M, Tietze F, Gahl WA (1986) Defective sialic acid egress from isolated fibroblast lysosomes of patients with Salla disease. Science 232:759-762

Seppala R, Tietze F, Krasnewich D et al. (1991) Sialic acid metabolism in sialuria fibroblasts. J Biol Chem 266:7456-7461

Stone DL, Sidransky E (1999) Hydrops fetalis: lysosomal storage disorders in extremis. Adv Pediatr 46:409-440

Suwannarat P (2005) Disorders of free sialic acid. Molec Genet Metab 85:85-87

Van der Ham M, Prinsen BHCMT, Huijmans JGM et al. (2007) Quantification of free and total sialic acid excretion by LC-MS/MS. J Chromatogr B 848:251-257

Van der Ham M, de Koning TJ, Lefeber D, Fleer A, Prinsen BHCMT, de Sain-van Der Velden MGM (2010) Liquid chromatography-tandem mass spectrometry assay for the quantification of free and total sialic acid in human cerebrospinal fluid. J Chromatogr B 878:1098-1102

Varho TT, Alajoki LE, Posti KM et al. (2002) Phenotypic spectrum of Salla disease, a free sialic acid storage disorder. Pediatr Neurol 26:267-273

Verheijen FW, Verbeek E, Aula N et al. (1999) A new gene, encoding an anion transporter, is mutated in sialic acid storage diseases. Nat Genet 23:462-465 